\title{
生薬の基原と品質評価
}

\author{
西 部三省
}

\section{The Plant Origins of Herbal Medicines and Their Quality Evaluation}

\author{
Sansei NISHIBE \\ Faculty of Pharmaceutical Sciences, Health Sciences University of Hokkaido, \\ Ishikari-Tobetsu, Hokkaido 061-0293, Japan
}

(Received February 18, 2002)

\begin{abstract}
The caulis (stem and leaf) of Trachelospermum jasminoides (Lindl.) Lem. (Apocynaceae) is listed as the plant origin of Luoshiteng in the Chinese Pharmacopeia. However, preparations from the caulis of Ficus pumila L. (Moraceae) or Psychotria serpens L. (Rubiaceae) are distributed on the Chinese market. The fruit of Forsythia suspen$s a$ Vahl (Oleaceae) is listed as the plant origin of Forsythia Fruit in the Chinese Pharmacopeia, although the fruits of two Forsythia species, F. suspensa and F. viridissima Lindley, are listed as the plant origins in the Japanese Pharmacopeia, and fruits of three Forsythia species, F. viridissima, F. koreana Nakai, and F. suspensa, are listed in the Korean Pharmacopeia. The whole plant of Plantago asiatica L. (Plantaginaceae) is listed as the plant origin of Plantago Herb in the Japanese Pharmacopeia, but the whole plants of two Plantago species, $P$. asiatica and $P$. depressa Wild, are listed as the plant origins in the Chinese Pharmacopeia. The leaves of two Plantago species, $P$. lanceolata L. and $P$. major L., are distributed as Plantain on the European market. Each of these herbal medicines is reviewed based on the differences in plant origins and their quality evaluation from the viewpoints of the morphological properties, chemical components, and biological activities, respectively.
\end{abstract}

Key words_- - herbal medicine; difference in plant origin; quality evaluation; morphological property; chemical component; biological activity

\section{はじめに}

生薬には歴史的に長年月にわたり用いられ伝承さ れたものが多くある。 これらの生薬は時代と共に変 遷を受けついで現代に至つている。しかしその過程 で用いられる地域や民族の違いにより, その生薬の 基原に違いが生じ, 同じ生薬名であってもその基原 を異にする生薬が市場に流通する結果となつている.

生薬は医薬品であり，すべて品質の同一性が強く 求められる。したがって生薬の基原及び品質を的確 に評価することが重要となってくる.

著者は北海道医療大学薬学部在職 26 年間にわた り, 生薬の品質評価という観点から, 絡石藤, 連 勢，オリーブ (樹皮，葉），秦皮，杜仲，車前草，

北海道医療大学薬学部（T061-0293 北海道石狩郡当別 町金沢 1757)

e-mail: nishibe@hoku-iryo-u.ac.jp

*本総説は, 平成 13 年度退官にあたり在職中の業績を 中心に記述されたものである.
車前子, 羅布麻, 刺五加, 日々草, 山査子, ゲンノ ショウコ，金銀花などの基原，その性状（外部形 態, 内部形態), 含有成分の解明, 生理活性試験, 確認試験, 成分含量の定量などの研究を行ってきた.

本稿では基原植物を全く異にする生薬が中国市場 に流通している絡石藤, 日本, 中国, 韓国の薬局方 に収載され，漢方方剂に古くから用いられ，重要な 生薬であるが，それぞれの国の薬局方により基原植 物の規定が異なっている連趐，世界中で広く用いら れ，多くの国の薬局方に収載されているが，国によ つて基原植物を異にする車前草（オオバコ）の 3 品 目について研究の概要を記述してみたい。なおその 詳細についてはそれぞれの原報をご覧いただきたい。

\section{絡石藤（Luoshiteng）}

基原植物絡石藤は祛風止痛, 咽喉腫痛, 行疠 止血, 通経絡などに用いられ, 祛風湿薬に分類さ れ, 神農本草経に収載される漢薬である。この効能 は西洋医学での抗炎症, 鎮痛, 解熱, 血液循環促 

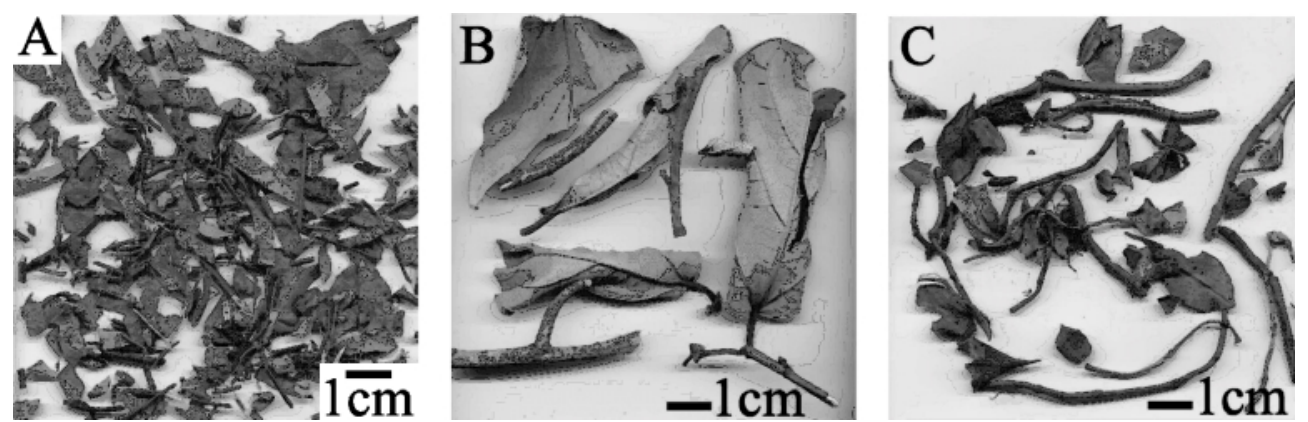

Fig. 1. Luoshiteng

A: T. jasminoides, B: F. pumila, C: P. serpens.

進, 免疫調整などの作用に相当するものと考えられ る. ${ }^{1)}$ その基原は中国薬典でタイワンテイカカズラ Trachelospermum jasminoides (Lindl.) Lem.

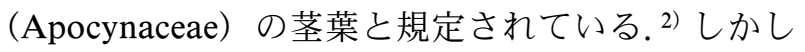
中国市場には $T$. jasminoides の他にオオイタビ Ficus pumila L. (Moraceae) 又はシラタマカズラPsychotria serpens L. (Rubiaceae) を基原とする絡石藤 が流通するとされている (Fig. 1). 3)

3 種の絡石藤は外部形態から $T$. jasminoides を基 原とするものと F. pumila を基原とするものについ てはそれぞれの葉の特徵から鑑別が容易であるが,

T. jasminoides とP. serpens を基原とするものは外 部形態が類似し，その鑑別はかなり困難である。し かし内部形態の観察からは，T. jasminoides を基原 とするものには長毛, 短毛, 異形細胞が, F. pumi$l a$ を基原とするものには多くの長毛と短毛が， $P$. serpens を基原とするものには長毛，短毛，多くの 針晶がそれぞれ観察され，3 種の鑑別は容易である (Fig. 2). ${ }^{4}$

含有成分 $T$. jasminoides の葉部からはフラボ ノイド化合物の apigenin, luteolin, apigenin 7-Oglucoside, apigenin 7-O-neohesperidoside, apigenin 7-O-rutinoside, apigenin 7-O-gentiobioside, luteolin 7-O-glucoside, luteolin $4^{\prime}-O$-glucoside, luteolin 7-Ogentiobioside を単離し, その構造を決定した. ${ }^{5)}$

T. jasminoides の茎部からはリグナン化合物の arctigenin, matairesinol, trachelogenin, nortrachelogenin, arctiin, matairesinoside, tracheloside, nortrachelosideを単離し，その構造を決定した (Chart 1). ${ }^{6,7)}$

これらのうち主成分は trachelogenin（含有量約
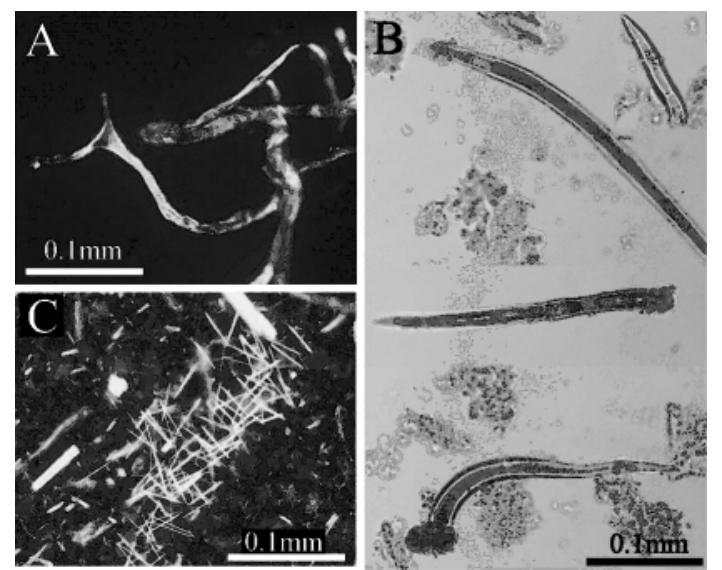

Fig. 2. Tissue Fragment of Luoshiteng

A: idioblast ( $T$. jasminoides), B: hair ( $F$. pumila), C: needle crystal (P. serpens), A, C: under polariscope, B: under microscope.

$0.5 \%$ ）と tracheloside（含有量 $0.3-0.4 \%$ ）であ る. ${ }^{8)}$

F. pumila の葉部からは rutin と chlorogenic acid を単離した。 F p pumila の茎部からは現在までのと ころリグナン化合物は単離されていない. ${ }^{4)}$

P. serpens の葉部からは rutinを単離した。 $P$. serpens の茎部からは現在までのところリグナン化 合物は単離されていない. ${ }^{4)}$

3 種の絡石藤の基原植物は含有成分に違いがみら れ, HPLCによる成分パターン分析からも鑑別が 可能で, とくに外部形態の特徵がみられない粉末生 薬やエキス剤の場合に有効である (Fig. 3). ${ }^{4}$

生理活性中国市場に出回っている絡石藤のう ち，T. jasminoides と F. pumila を基原とするもの について，いずれも葉部と茎部に分別し，それぞれ の水抽出エキスを製した。水抽出エキス及び単離し 
<smiles>O=c1cc(-c2ccc(O)cc2)oc2cc(O)cc(O)c12</smiles>

apigenin

7- $O$-glucoside : $\mathrm{R}=$ glucosyl

7- $O$-neohesperidoside : $\mathrm{R}=$ neohesperidosyl

7-O-rutinoside : R=rutinosyl

7-O-gentiobioside : $\mathrm{R}=$ gentiobiosyl

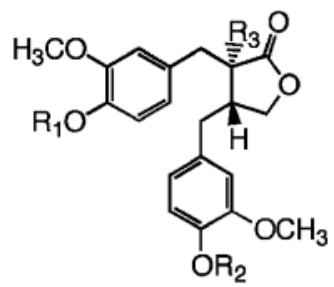

$$
\begin{aligned}
& \text { arctigenin : } \mathrm{R}_{1}=\mathrm{R}_{3}=\mathrm{H}, \mathrm{R}_{2}=\mathrm{CH}_{3} \\
& \text { matairesinol : } \mathrm{R}_{1}=\mathrm{R}_{2}=\mathrm{R}_{3}=\mathrm{H} \\
& \text { trachelogenin }: \mathrm{R}_{1}=\mathrm{H}, \mathrm{R}_{2}=\mathrm{CH}_{3}, \mathrm{R}_{3}=\mathrm{OH} \\
& \text { nortrachelogenin : } \mathrm{R}_{1}=\mathrm{R}_{2}=\mathrm{H}, \mathrm{R}_{3}=\mathrm{OH} \\
& \text { arctiin : } \mathrm{R}_{1}=\text { glucosyl, } \mathrm{R}_{2}=\mathrm{CH}_{3}, \mathrm{R}_{3}=\mathrm{H} \\
& \text { matairesinoside : } \mathrm{R}_{1}=\text { glucosyl, } \mathrm{R}_{2}=\mathrm{R}_{3}=\mathrm{H} \\
& \text { tracheloside }: \mathrm{R}_{1}=\text { glucosyl, } \mathrm{R}_{2}=\mathrm{CH}_{3}, \mathrm{R}_{3}=\mathrm{OH} \\
& \text { nortracheloside }: \mathrm{R}_{1}=\text { glucosyl, } \mathrm{R}_{2}=\mathrm{H}, \mathrm{R}_{3}=\mathrm{OH}
\end{aligned}
$$<smiles>[2H]c1ccc(-c2cc(=O)c3c(O)cc(O)cc3o2)cc1[2H]</smiles>

luteolin

7- $O$-glucoside : $\mathrm{R}_{\mathbf{1}}=$ glucosyl, $\mathrm{R}_{\mathbf{2}}=\mathrm{H}$

4'- $O$-glucoside : $\mathrm{R}_{1}=\mathrm{H}, \mathrm{R}_{2}=$ glucosyl

7-O-gentiobioside : $\mathrm{R}_{1}=$ gentiobiosyl, $\mathrm{R}_{2}=\mathrm{H}$
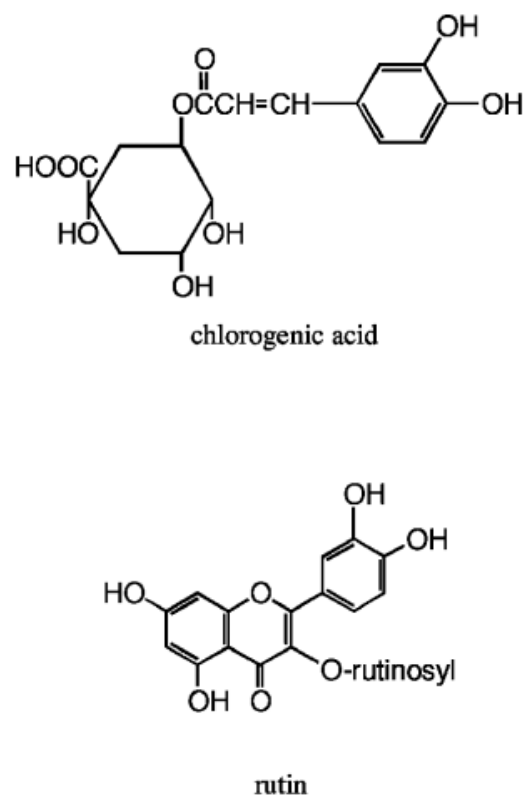

Chart 1

た成分について，その薬効との関連が考えられる生 理活性の検討を行つた。

\section{フラボノイド成分の生理活性}

Xanthine oxidase 阻害作用 : 抗炎症, 鎮痛の効 果を目的に，痛風への作用を指標とした xanthin oxidase 阻害活性の検討を行った. ${ }^{5)}$

基質として xanthin を用い，290 nm での UV 吸 収を用いた Kalckar 変法によるxanthin oxidase 活 性の測定を行った。その結果 T. jasminoides 葉部の エキスにのみ $1.5 \mathrm{mg} / \mathrm{ml}$ で $64.1 \%, 1.0 \mathrm{mg} / \mathrm{ml}$ で 47.4\% の阻害活性を認めた。 T. jasminoides 葉部か ら単離したフラボノイド化合物のうち apigenin, luteolin, luteolin 4'-O-glucoside にそれぞれ $\mathrm{IC}_{50}(\mu \mathrm{M})$ : 1.7, 2.4, 2.0 の阻害活性を認めた.

従来フラボノイド配糖体に阻害活性は認められな いとされていた。本研究で B 環の $4^{\prime}$ - 位が配糖体化
されたものに aglycone とほぼ同等の阻害活性を認 めたことは, 今後の luteolin 誘導体の医薬品開発に 際し， 4' - 位の修飾に関する有意義な情報を得るこ とができたものと考える.

$\boldsymbol{\beta}$-Hexosaminidase 阻害作用: 抗アレルギー作 用のスクリーニングにはラットの肥満細胞を用いる のが一般的であるが，最近 IgE-レセプターをもつ $\mathrm{RBK}-2 \mathrm{H} 3$ 細胞を用いた $\beta$-hexosaminidase 阻害活性 が知られるようになった。

Kitaoka らの方法に準じ, フラボノイド化合物に ついて $\beta$-hexosaminidase 阻害活性を調べた結果, luteolin $4^{\prime}$ - $O$-glucoside $\left[\mathrm{IC}_{50}: 17.1 \mu \mathrm{g} / \mathrm{ml}\right.$, 対照化合 物 baicalein, $\left.\mathrm{IC}_{50}: 10.8 \mu \mathrm{g} / \mathrm{ml}\right]$ に高い阻害活性を認 めた. 9) なお luteolin 4'-O-glucosideには他に cAMP phosphodiesterase 阻害活性 ${ }^{10)}$ や Interleukin-5 阻害 活性が報告されており, ${ }^{11)}$ 抗アレルギー作用との関 

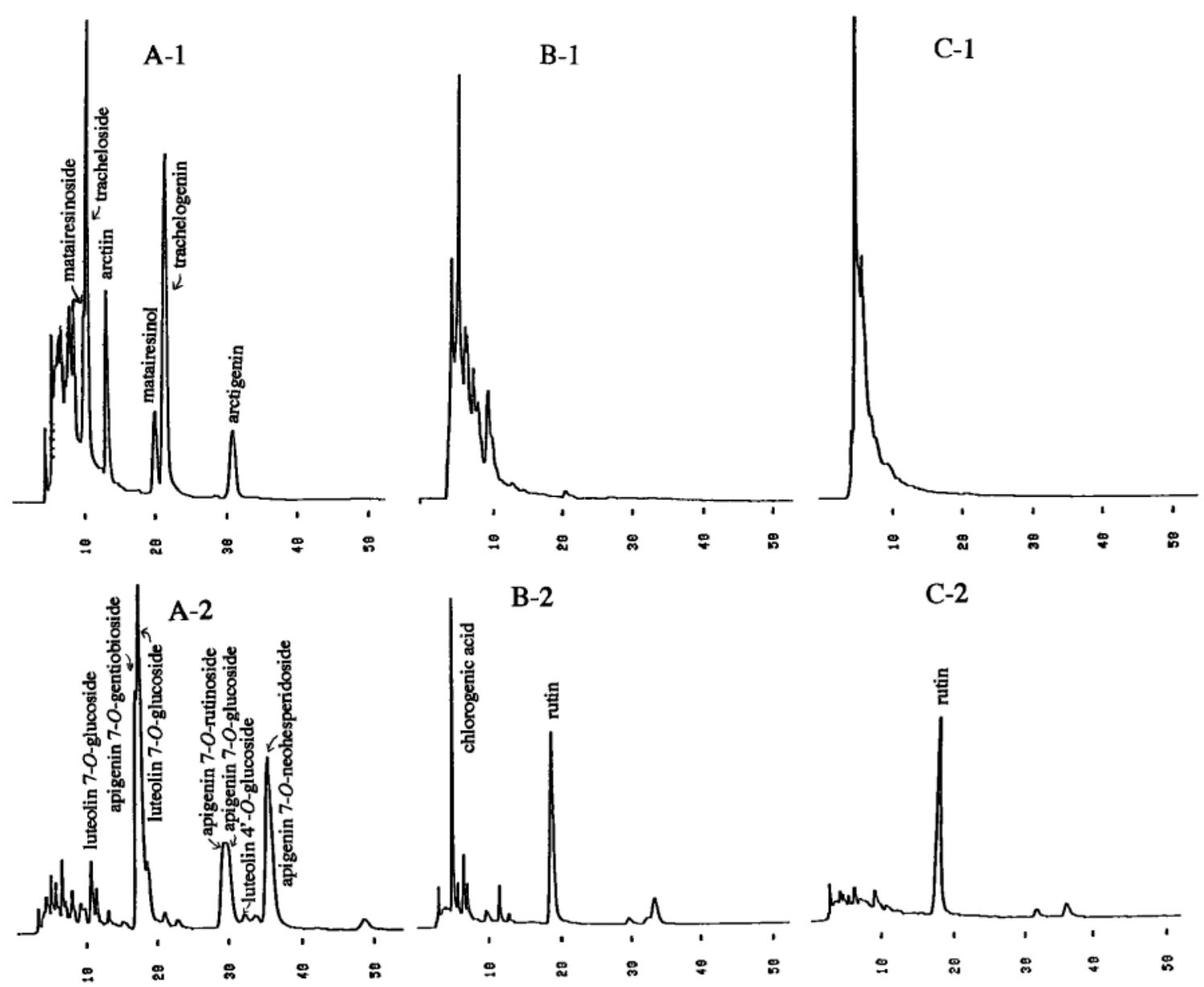

C-2

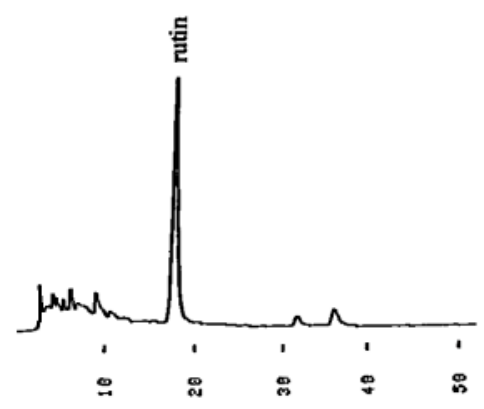

Fig. 3. HPLC Chromatograms of Methanol Extracts of Luoshiteng

Stem part: A-1: T. jasminoides, B-1: F. pumila, C-1: P. serpens. Conditions: column, Develosil ODS-5 $(4.6 \times 250 \mathrm{~mm}) ; \mathrm{mobil}$ phase, $\mathrm{MeOH}: \mathrm{H}_{2} \mathrm{O}: \mathrm{AcOH}$ $(35: 45: 3)$; flow rate, $0.5 \mathrm{ml} / \mathrm{min}$; column temp., $35^{\circ} \mathrm{C}$; detector, UV $280 \mathrm{~nm}$.

Leaf part: A-2: T. jasminoides, B-2: F. pumila, C-2: P. serpens. Conditions: column, Develosil ODS-5 $(4.6 \times 250 \mathrm{~mm})$; mobil phase, $\mathrm{MeOH}: \mathrm{H}_{2} \mathrm{O}: \mathrm{AcOH}(10$ : $30: 2$ ); flow rate, $1.0 \mathrm{ml} / \mathrm{min}$; column temp., $35^{\circ} \mathrm{C}$; detector, UV $330 \mathrm{~nm}$.

連が強く示唆された。

\section{リグナン成分の生理活性}

気管平滑筋弛緩作用： 絡石藤を喘息型慢性気管 支炎に用いるとの報告があり, 気管平滑筋弛緩作用 について検討を行つた. ${ }^{6)}$

モルモットより気管を摘出し，高木らの方法に準 じて気管鎖状標本を作製，ヒスタミンで気管平滑筋 を収縮後，各エキスを投与し，その弛緩作用を調べ た. その結果, T. jasminoides を基原とする絡石藤 の茎部エキスのみに $10^{-4} \mathrm{~g} / \mathrm{ml}$ の濃度で驰緩作用を 認め, 他のエキスには認められなかった。

茎部エキスから単離した成分について活性本体の 解明を行った。 Arctigenin, matairesinol, trachelogenin 及び nortrachelogenin にいずれも $10^{-4} \mathrm{~g} / \mathrm{ml}$ の濃度で顕著な気管支平滑筋弛緩作用を認めた。な
おこれらの配糖体には弛緩作用は認められなかつた。

$\mathrm{Ca}^{2+}$ アンタゴニスト作用： 単離したリグナン 成分について $\mathrm{Ca}^{2+}$ アンタゴニスト作用を調べたと ころ, trachelogenin に顕著な作用が認められ，そ の活性は verapamil の 1/6 であった. ${ }^{12)}$ Trachelogenin は高血圧自然発症ラット（SHR）を用いた in vivo 実験でも明らかな降圧作用を示した. ${ }^{12)}$

活性酸素産生抑制作用： スーパーオキシド産生 は自己免疫疾患のリュウマチや炎症に大きく関与す ることから活性酸素産生抑制作用を検討した. $\left.{ }^{6}\right)$

活性酸素産生抑制測定にはフェリチトクロム C を用いた. Arctigenin $\left[\mathrm{IC}_{50}(\mu \mathrm{M}): 3\right]$ 及び nortrachelogenin $\left[\mathrm{IC}_{50}(\mu \mathrm{M}): 8\right]$ に活性を認め, とくに arctigenin に慢性関節リウマチ薬 auranofin $\left[\mathrm{IC}_{50}\right.$ $(\mu \mathrm{M})$ ：7.5] より高い活性が認められた。さらに ar- 
ctigenin は炎症と関連する Interleukin-6 に活性阻害 効果を示すことが報告されている. ${ }^{13)}$

血小板凝集抑制作用：血小板凝集抑制作用（抗 ADP 誘導血小板凝集作用）については Born の方 法に準じて行った. ${ }^{6)}$ その結果, 試料 $0.5 \mathrm{mg} / \mathrm{ml}$ で aspirin $24.8 \pm 6.6 \%$ に対し, trachelogenin に 35.4土 $7.6 \%$, arctigenin $34.2 \pm 7.6 \%$ の抑制がそれぞれ 認められた。

発がんプロモーター抑制作用: Arctigenin, arctiin, trachelogenin, trachelosideについて発がんプ ロモーター抑制作用の一次スクリーニングとして知 られるEB (Epstein-Barr) ウイルス活性化抑制試 験を行った. ${ }^{14,15)}$ これはパーキットリンパ腫由来の EB ウイルス非産生培養細胞である Raji 細胞を指示 細胞として用い, 強力な発がんプロモーターである 12-O-tetradecanoylphorbor-13-acetate（TPA）によ り誘発されるEB ウイルス早期抗原 (EBV-EA) の 誘発率を上咽頭がん患者の血清を用いて間接蛍光抗 体法により測定するものである.

4 種のリグナン化合物はいずれも EBV-EA 発現 に対してほぼ同程度の抑制効果を示した。 さらに dimethylbenz [a] anthracene (DMBA) をイニシィ エーター, TPA をプロモーターとするマウス皮膚 二段階発がん実験において, 陽性コントロール群で はプロモーション開始 10 週間後にはすべてのマウ スに腫瘍が発生するのに対し, arctiin 及び arctigenin, tracheloside 及び trachelogenin 塗布群では 15 週間後でも約 $50 \%$ の発生率であった。 また 1 匹あ たりの平均腫瘍発生個数においてもコントロール群 に比較し抑制効果が認められた。

さらに arctiin について Sprague-Dawley (SD) 系 雌ラットを用い, 乳がん予防効果を検討した. ${ }^{16)}$ PhIP (2-amino-1-methyl-6-phenylimidazo [4, 5-b] pyridine）により誘発される乳腺でのがん発症は $\operatorname{arctiin}$ の経口投与により用量依存的にプロモーシ ヨンの段階で抑制されることが明らかとなった.

\section{Arctiin 及び tracheloside の腸内細菌による代謝 :}

リグナン化合物の secoisolariciresinol や matairesinol が腸内細菌により phytoestrogen の 1 つである enterolactone に代謝されることが知られている. Arctiin 及び tracheloside にがん予防効果が認められ たことから, in vitro でのラットの腸内細菌による 代謝を検討した. ${ }^{17,18)}$ In vitro 実験では $\operatorname{arctiin}$ から enterolactone への変換は確認できなかったが, フ インランドの研究チームとの共同研究で SD 系雄ラ ットを用いた $\operatorname{arctiin} 25 \mathrm{mg} / \mathrm{kg}$ の経口投与による in vivo 実験では, 尿中に enterolactone が有意に増加 していることを認め（第 1 日目の尿中に $107 \mu \mathrm{g}$ / day, 第 2 日目の尿中に $91 \mu \mathrm{g} /$ day), arctiin も enterolactone の前駆物質の 1 つになるものと推測で きた. ${ }^{19)}$

リグナン化合物の腸内細菌による代謝については さらに連趟の項で記述する.

まとめ 絡石藤はこれまでの結果をふまえれば T. jasminoides に含有されるフラボノイドとリグナ ン成分が生理活性成分とみなすことができる. した がつて中国薬典に規定される T. jasminoides を基原 とするものを正品とするのが理にかなったものと考 える。

\section{連勢 (Forsythia Fruit)}

基原植物連趐は神農本草経に収載され, 清熱 解毒薬に分類される漢薬で, 消炎, 利尿, 排膿, 解 毒の効があるとされ, 種々の化膿症や皮膚病の治療 薬として荊芥連䞨湯, 柴胡清肝湯などの漢方方剂に 配剂され, 古くから用いられている重要な生薬であ る.

連趐はモクセイ科 (Oleaceae) レンギョウ属植物 の果実から調製され, 日本薬局方には第 9 改正から 収載され，その基原植物に第 11 改正まではレンギ ヨウ Forsythia suspensa Vahl, F. viridissima Lindley 又は F. koreana Nakai の 3 種をあてていた。第 12 改正からは日本の市場に流通がみられないF. koreana が削除され，F. suspensa 又は F. viridis$\operatorname{sima}$ の 2 種があてられている。 また連趐は韓国及 び中国でも薬局方に収載されている. 韓国薬局方で はその基原植物に F. viridissima, F. koreana 又は $F$. suspensa の 3 種をあてている. 中国薬典では $F$. suspensa のみをあてている.

3 種の基原植物の果実は種により外部形態並びに 内部形態にそれぞれの特徵があり，それぞれの連趣 の鑑別は可能である. ${ }^{20)}$ すなわち外部形態では $F$. suspensa は長卵形, F. viridissima は広卵形, F. koreana は長卵形で果柄の上部分がくぼみ, 果皮表 面はいずれも発達した瘤状の皮目がみられる。内部 形態ではF. suspensaにおいては, 石細胞は維管束 に接して観察される。いずれも果皮表面にはクチク 


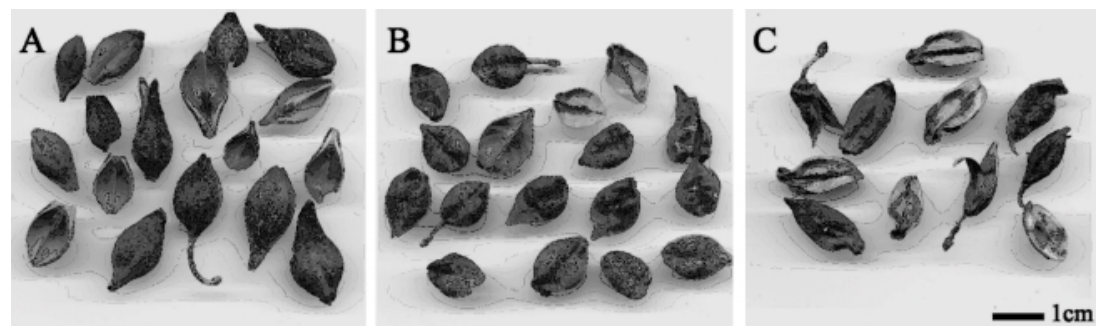

Fig. 4. Forsythia Fruit

A: F. suspensa, B: F. viridissima, C: F. koreana.

ラ層が発達しているが，F. suspensa と F. koreana は鋸状であり，F. viridissima は平滑である(Fig. 4)。

含有成分 3 種の連趟からはいずれも共通成分 としてトリテルペノイド化合物の betulinic acid, ursolic acid, oleanolic acid 並びにフラボノイド化合物 の rutin を単離した. ${ }^{21-23)}$

F. suspensa を基原とする連趐からはリグナン化 合物の phillygenin, (+)-pinoresinol, phillyrin, (+)pinoresinol $\beta$-D-glucoside（いずれもフロフラン型リ グナン), フェニルエタノイド配糖体の forsythiaside, suspensaside を単離し, その構造を決定した (Chart 2). 21,22,24-26)

F. viridissima を基原とする連趐からはリグナン 化合物の arctigenin, matairesinol, arctiin, matairesinoside（いずれもジアリールブチロラクトン型リ グナン), フラボノイド化合物の quercitrin, フェニ ルエタノイド配糖体の acteoside, $\beta$-hydroxyacteo-

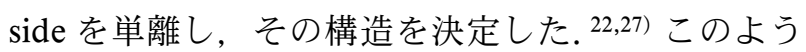
にF. suspensa とF. viridissima 基原とする連趐 には含有成分に違いがみられた。

F. koreana を基原とする連趟はリグナン化合 物, フェニルエタノイド配糖体いずれも F. suspen$s a$ と F. viridissima の両化合物をすべて含有してい た. ${ }^{23,28)}$

3 種の連趗はいずれもフェニルエタノイド配糖体 が主成分（含有量約 $0.8 \%$ ）をなしていた. ${ }^{29,30)}$

現在の日本薬局方収載 2 種の連趐の基原には明ら かな含有成分の違いがみられ，HPLCによる成分 パターン分析からも鑑別が可能で, 粉末生薬やエキ ス剤の基原の鑑別に有効である（Fig. 5).

さらに連趟の基原植物 F. viridissima は DNA sequence 解析においても他の Forsythia 属とは明らか な相違が認められた (Fig. 6).31) 確認試験＼cjkstart現在の日本薬局方には確認試験にト リテルペノイドとフラボノイドによる呈色反応が記 載されている，著者はあらたに連趗の特有成分の forsythiaside や acteoside の構造が有するフェネチ ルアルコール基を利用し， 4- アミノアンチピリン とインドフェノール縮合反応を適用した呈色反応を 提唱した. ${ }^{32)}$ しかし本法ではフェニルエタノイド配 糖体の存在は確認できても，F. suspensa とF. viridissima の基原の鑑別はできない. そこで 2 種の 基原の鑑別を目的に TLC 法を検討した. ${ }^{33)}$

連趐の粉末をメタノールにて加温抽出し, そのろ 液を試料溶液とした。この液につき, 薄層クロマト グラフ法により試験を行った。展開溶媒に酢酸エチ ルエステル/酢酸/水 $(7: 2: 1)$ を用い, スポット の検出は塩化第二鉄試液の噴霧によって行つたが,

F. suspensa を基原とする連趟の主成分 forsythiaside と F. viridissima を基原とする連趐の主成分 acteoside のスポットはほとんど同じ $R f$ 值を示し, フ エニルエタノイド配糖体のみを指標成分とする TLC での両者の鑑別は困難であった。しかし F. viridissima は quercitrin を含有し, F. suspensa は含 有しないことから, 連趐の指標成分に forsythiaside と quercitrinを用い, quercitrinのスポットの有無 を加味すれば, 両者の鑑別は可能となった。なお forsythiaside の塩化第二鉄試液噴霧による検出は $0.25 \mathrm{mg} / \mathrm{ml}$ の濃度まで確実であり, 連趐市場品の 含量測定結果並びに中国薬典記載の forsythiaside 含量規定 $0.15 \%$ 以上に十分対応できる検出限界で あった。

生理活性 2 種の連趐は日本薬局方では同じ連 趐とされるが，両者には明らかな成分の相違が知ら れることとなった。このことから 2 種についていく つかの生理活性の比較検討を行つた. 
<smiles>COc1cc([C@@H]2OC[C@H]3[C@H]2CO[C@H]3c2ccc(O)c(OC)c2)ccc1O</smiles>

pinoresinol : $\mathrm{R}=\mathrm{H}$

pinoresinol $\beta$-D-glucoside : $\mathrm{R}=$ glucosyl<smiles>COc1cc(C[C@@H]2COC(=O)[C@@H]2Cc2ccc(O)c(O)c2)ccc1O</smiles>

matairesinol : $\mathrm{R}_{1}=\mathrm{R}_{2}=\mathrm{H}$ arctigenin : $\mathrm{R}_{1}=\mathrm{H}, \mathrm{R}_{2}=\mathrm{CH}_{3}$ matairesinoside : $\mathrm{R}_{1}=$ glucosyl, $\mathrm{R}_{2}=\mathrm{H}$ arctiin : $\mathrm{R}_{1}=$ glucosyl, $\mathrm{R}_{2}=\mathrm{CH}_{3}$<smiles>COc1ccc([C@@H]2OC[C@H]3[C@H](c4ccc(O)c(OC)c4)OC[C@@H]32)cc1O</smiles>

phillygenin : $\mathrm{R}=\mathrm{H}$ phillyrin : $R=$ glucosyl<smiles>O=c1c(O)c(-c2ccc(O)c(O)c2)oc2cc(O)cc(O)c12</smiles>

rutin : $\mathrm{R}=$ rutinosyl quercitrin : $\mathrm{R}=$ =rhamnosyl

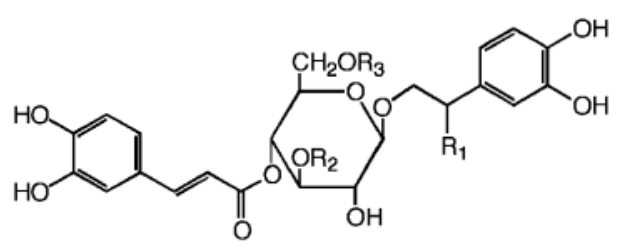

forsythiaside : $\mathrm{R}_{1}=\mathrm{R}_{2}=\mathrm{H}, \mathrm{R}_{3}=$ rhamnosyl

suspensaside : $\mathrm{R}_{1}=\mathrm{OH}, \mathrm{R}_{2}=\mathrm{H}, \mathrm{R}_{3}=$ rhamnosyl

acteoside : $\mathrm{R}_{1}=\mathrm{R}_{3}=\mathrm{H}, \mathrm{R}_{2}=$ rhamnosyl

$\beta$-hydroxyacteoside : $\mathrm{R}_{1}=\mathrm{OH}, \mathrm{R}_{2}=$ rhamnosyl, $\mathrm{R}_{3}=\mathrm{H}$

Chart 2

抗菌作用： 適応症の 1 つが細菌感染症とみなさ れることから, 抗菌性のあることが考えられる. 黄 色ブドウ球菌 Staphylococcus aureus 寺島株を用 い, 希釈法により抗菌作用を調べた. ${ }^{26,34)} F$. suspensa を基原とした連趐の水抽出エキスは，その最 低阻止濃度（MIC）が生薬に対して $6 \mathrm{w} / \mathrm{v} \%$ であ るのに対し，F. viridissima を基原とした連趐は 14 w/v％という結果を得た。 その抗菌成分は forsythiaside (MIC $3.2 \mathrm{mM})$, suspensaside (4.1 mM), acteoside $(3.2 \mathrm{mM}), \beta$-hydroxyacteoside $(2.0 \mathrm{mM})$ であった。 F. suspensa を基原とした連趐は，F. viridissima を基原とした連趐に比べて，これらの抗 菌成分の含量が約 5 倍高く, 両者の抗菌活性の差 は, その抗菌成分の違いよりも, むしろ含量の差に 基づくものと考えられる.
酵素阻害作用： 連趐は配合されている漢方方剂 の薬効から抗アレルギー, 抗炎症作用が考えられ る. 抗アレルギー作用の第一次スクリーニングとし $\tau$ cAMP-phosphodiesterase 阻害活性と 5-lipoxygenase 阻害活性を検討した. ${ }^{35-37)}$ 牛の心臓からの cAMP-phosphodiesterase の阻害活性は $F$. suspensa を基原とした連趟のほうが高い阻害活性を示した。 フェニルエタノイド配糖体, とりわけ forsythiaside と suspensaside が比較的高い阻害活性を示した。一 方 acteoside と $\beta$-hydroxyacteoside は弱い活性を示 したにすぎない。両者の化学構造は rhamnose の glucose への結合位置が $1 \rightarrow 6$ か $1 \rightarrow 3$ の違いのみで あるにもかかわらず阻害活性に明らかな差が認めら れたことは興味あることである (Table 1)。

連趐の薬効の発現の 1 つにはフェニルエタノイド 
A

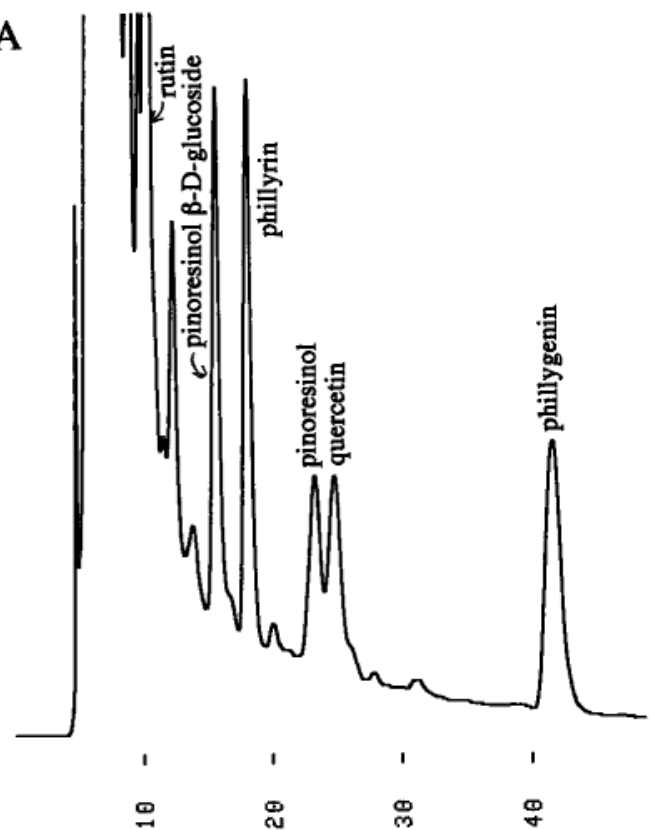

B

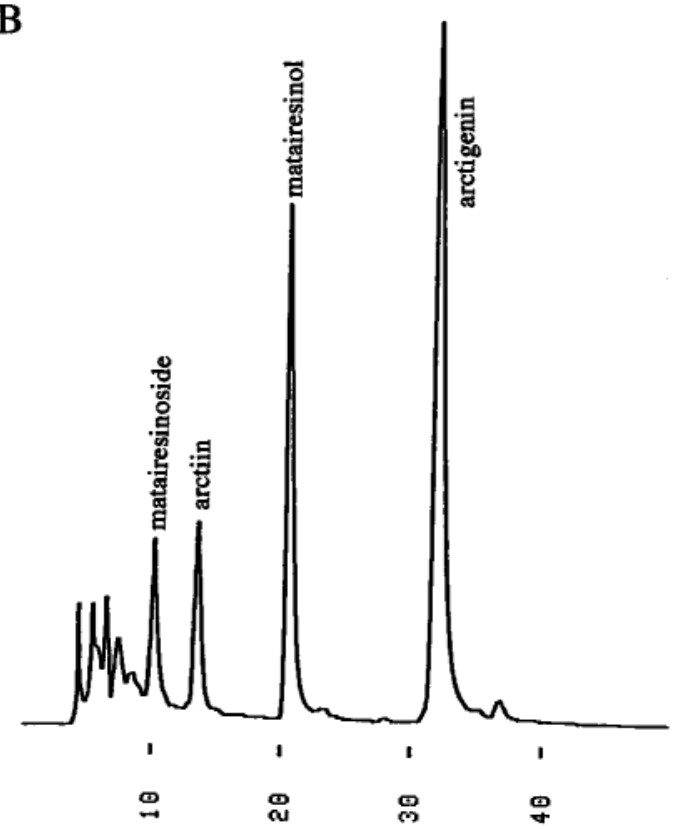

Fig. 5. HPLC Chromatograms of Methanol Extracts of Forsythia Fruit

A: F. suspensa, B: F. viridissima, Conditions: column, Develosil ODS-5 (4.6×250 mm); Mobil phase, $\mathrm{MeOH}: \mathrm{H}_{2} \mathrm{O}: \mathrm{AcOH}(35: 45: 3)$; flow rate, $0.5 \mathrm{ml} /$ min; column temp., $35^{\circ} \mathrm{C}$; detector, UV $280 \mathrm{~nm}$.

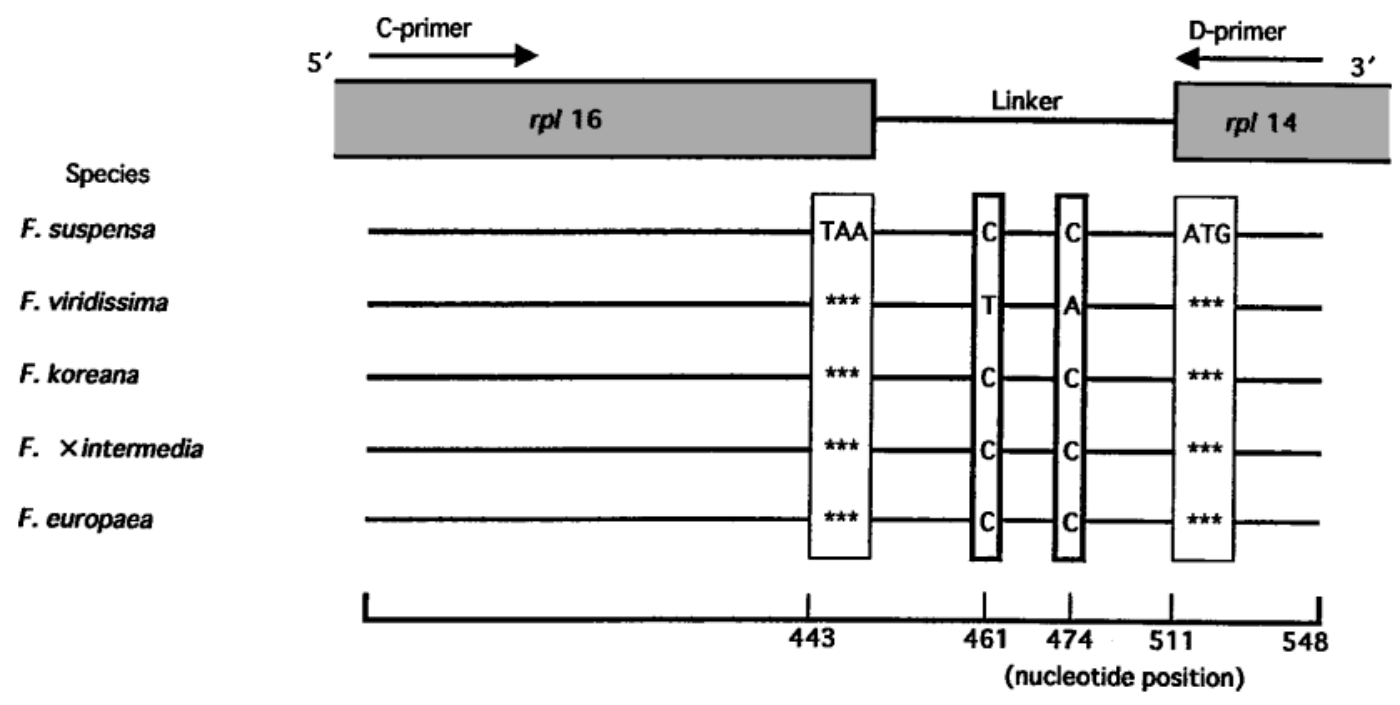

Fig. 6. Comparison of rpl 16-rpl 14 Sequences among Forsythia Species

Table 1. Enzyme Inhibitory Activity

\begin{tabular}{lccc}
\hline \hline & $\begin{array}{c}\text { cAMP } \\
\text { phosphodiesterase* }\end{array}$ & & 5-lipoxygenase** \\
\cline { 2 - 2 } & $\mathrm{IC}_{50}\left(\times 10^{-5} \mathrm{M}\right)$ & & $\mathrm{IC}_{50}\left(\times 10^{-6} \mathrm{M}\right)$ \\
\hline Forsythiaside & 11.0 & & 2.50 \\
Suspensaside & 18.3 & 7.97 \\
Acteoside & $>50$ & 5.27 \\
$\beta$-hydroxyacteoside & $>50$ & 19.3 \\
\hline
\end{tabular}

* From beef heart. ** From rat peritoneal cells.
配糖体成分が phosphodiesterase を阻害し, cAMP の分解を防ぎ，体内に cAMP を大量に作り出し， 肥満細胞から化学伝達物質の放出を防ぐ効果が関与 しているのではないかと考えられる.

5-lipoxygenase はアラキドン酸代謝系でのロイコ トリエン生成に関与する酵素である。 ラット腹腔内 多核白血球アラキドン酸代謝系における5-lipoxygenase 阻害活性では，それぞれのフェニルエタノ 
イド配糖体に強い阻害活性を認めた。連趣の薬効の 発現にはフェニルエタノイド配糖体成分の 5-lipoxygenase 阻害活性も関与しているのではないかと推 察される.このようにいずれの酵素阻害活性におい てもF. suspensaの主成分は F. viridissima の主成 分に比して高い阻害活性を示した.

さらに最近リグナン成分の pinoresinol にサイト カインの 1 つである TNF- $\alpha$ ( Tumor Necrosis Factor）の産生抑制効果が報告され, ${ }^{38)}$ リグナン成 分も抗炎症, 抗アレルギー作用に関与している可能 性が示唆された。

降圧作用： 連趐には降圧作用があるとの報告が ある. ${ }^{39)}$ In vivo でのウレタン麻酔, 高血圧自然発 症ラット (SHR) での降圧作用を調べた. ${ }^{36)}$

F. suspensa 基原とした連趐の水抽出エキスは 体重 $10 \mathrm{mg} / \mathrm{kg}$ 後肢静脈内投与で $35 \mathrm{mmHg}$ の持続 性の降圧作用を認めたのに対し，F. viridissimaを 基原とした連趯の水抽出エキスは一過性の降圧作用 を認めたに過ぎず，両者の作用に明らかな違いが認 められた。 その持続性降圧成分の 1 つは cAMPphosphodiesterase に高い阻害活性の認められてい る suspensaside であった。

リグナン化合物の腸内細菌による代謝 : 疫学調 査から血中あるいは尿中の phytoestrogen の含量の 多いヒトほどホルモン依存性の乳がんや虚血性心疾 患に罹る危険性が低いことが報告されている. ${ }^{40) さ ~}$ らに更年期障害のほてり, のぼせ, 動悸, 異常な発 汗をはじめとする諸症状を改善することも報告され

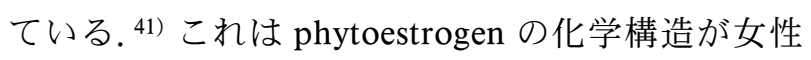
ホルモンの構造に類似しており, エストロゲンレセ プターに結合することにより生理的にホルモン活性 を生じさせることによるものである.

ヒトリグナン（mammalian lignan）といわれる phytoestrogen の enterolactone や enterodiol はライ 麦をはじめとする穀類に含まれるリグナン成分の matairesinol や secoisolariciresinol からヒトの腸内 細菌によって代謝され，つくられることはすでに知 られている. ${ }^{42)}$

著者とフィンランドの研究チームは enterolactone のあらたなる前駆物質を求めて連趐から得ら れたリグナン化合物についてヒトの腸内細菌を用い た in vitroでの代謝実験を行った. ${ }^{43)}$ その結果 pinoresinol は $55 \%$, matairesinol は $62 \%$, arctigenin
は 4\%がそれぞれ enterolactone に代謝されること を見出した。この実験で pinoresinol の腸内細菌に よる代謝経路が Lewis らによって報告されているレ ンギョウ葉中のリグナン生合成経路44) と全く同じで あったことは大変興味あることである（Fig. 7).

主要リグナン成分に pinoresinol 及びその配糖体 を含有する連趟は enterolactone 前駆物質の供給源 となることが期待できる. 事実 SD 系雄ラットを用 いた連趟水抽出エキス $100 \mathrm{mg} / \mathrm{kg}$ の経口投与によ る in vivo での実験で, 尿中に enterolactone が有意 に増加していることを認めている（第 1 日目の尿中 に $55 \mu \mathrm{g} / \mathrm{day}$ ，第 2 日目の尿中に $60 \mu \mathrm{g} / \mathrm{day}) .{ }^{19)}$

まとめ 日本薬局方では同属植物とは「通例, 同様の成分, 薬効を有する生薬として用いられてい る原植物」と規定されている.これまでの結果をふ まえれば, 日本薬局方収載連趣の基原植物 F. suspensa とF. viridissimaの同一性には疑問があり, 基原の再考が必要と思われる.

\section{車前草（Plantago Herb）}

基原植物 オオバコは西洋においても東洋にお いても身近な植物としてょく知られている. 日本で は干して煎じたものは咳止め, 消炎, 利尿などの民 間薬として用いられてきた。

日本ではオオバコPlantago asiatica L. (Plantaginaceae）の花期の全草がシャゼンソウ（車前草） として第 7 改正日本薬局方から収載され, 重要な生 薬の 1 つとなっている. ヨーロッパではハーブとし て茶剤，シロップ剂をはじめとする多くの製品が市 場に出回っている.

日本ではオオバコ全草が生薬の車前草として用い られる他に, エキス製剤が医療用医薬品として認め られ，鎮咳，去痰などを目的に病院で用いられてい る.

ヨーロッパでもハーブ・オオバコ（Plantain, Plantago Herb）を薬局方に収載している国がいく つかあるが基原植物がそれぞれの国により異なつて いる. ${ }^{45)}$ 日本ではオオバコP. asiatica のみである が, 中国ではP. asiatica の他にムジナオオバコP. depressa Wildがあてられている. ヨーロッパでは ほとんどがへラオオバコP. lanceolata L. である. フランスではセイヨウオオバコ P. major L. やP. media L. もあてられている. 一方富山医科薬科大 学の森田, 吉崎らはパラグアイの薬草調査で $P$. 
<smiles>COc1cc([C@@H]2OC[C@H](Cc3ccc(C[C@H]4OC[C@@H]5[C@H](c6ccc(O)c(OC)c6)OC[C@H]45)c(OC)c3)[C@H]2CO)ccc1O</smiles>

Pinoresinol
Lariciresinol<smiles>COc1cc(C[C@@H](CO)[C@H](CO)Cc2ccc(O)c(OC)c2)ccc1O</smiles><smiles>COc1cc(C[C@@H]2COC(=O)[C@@H]2Cc2ccc(O)c(OC)c2)ccc1O</smiles>

Matairesinol

$$
\downarrow
$$<smiles>CC(C)C</smiles><smiles>O=C1OC[C@H](Cc2cccc(O)c2)[C@@H]1Cc1cccc(O)c1</smiles>

Fig. 7. Proposed Metabolic Pathway of Pinoresinol to Enterodiol and Enterolactone

tomentosa Lam. の全草がパラグアイ市場に出回つ ており, その用途は鎮痤, 抗炎症, こしけ, 腔炎と 従来の車前草とは異なる用い方を報告している. ${ }^{46)}$

車前草の基原植物の外部形態には根の形態に特徵 があり，P. asiatica，P. major はひげ根を持つ種で あり, P. depressa, P. lanceolata は主根を持つ種で ある (Fig. 8). ${ }^{47)}$

含有成分 日本でのP. asiatica, 中国での $P$. depressa, ヨーロッパでの P. major と P. lanceola$t a$ の 4 種の基原植物についてその成分研究を行つ た。 13 種のフェニルエタノイド配糖体，9種のフラ ボノイド化合物及び 5 種のイリドイド配糖体を単離 し，その構造を決定した（Table 2)，(Chart 3, 4, 5). ${ }^{48-56)}$

フェニルエタノイド配糖体からは基原植物に plantamajosideを主成分とする種（含有量 2-4\%) と acteoside を主成分とする種（含有量 3-8\%）の 2 群に分けられた. ${ }^{47)}$ なお根の形態からは前者がひ げ根をもつ種であり, 後者が主根を持つ種と興味あ る結果を得た。
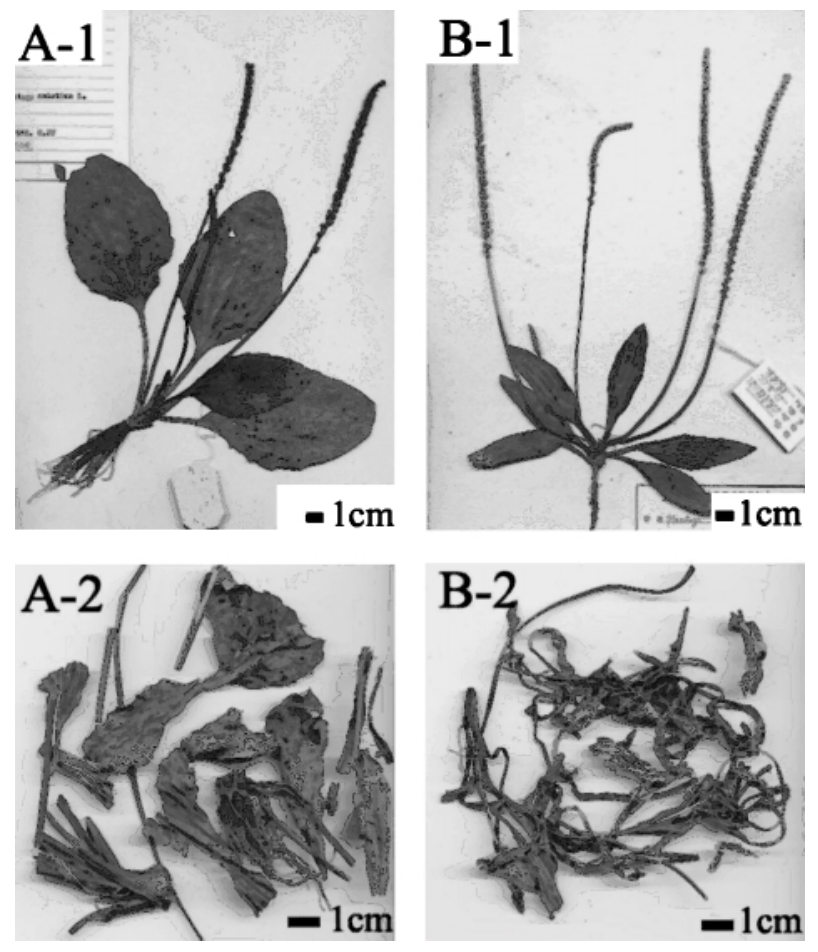

Fig. 8. Plantago Herb A: $P$. asiatica, B: $P$. depressa, 1: herbarium specimen, 2: herbal medicine, $\boldsymbol{a}: 1 \mathrm{~cm}$. 
Table 2. Compounds from Plantago Herb

\begin{tabular}{|c|c|c|c|}
\hline Origin & Phenylethanoid & Flavonoid & Iridoid \\
\hline P. asiatica & $\begin{array}{l}\text { Plantamajoside } \\
\text { Hellicoside } \\
\text { Acteoside } \\
\text { Isoplantamajoside } \\
\text { 3,4-dihydroxyphenethylalcohol-6- } \\
O \text {-caffeoyl- } \beta \text {-D-glucoside } \\
\text { Plantasioside }\end{array}$ & $\begin{array}{l}\text { Apigenin } \\
\text { Luteolin } \\
\text { Cosmosiin } \\
\text { Luteolin 7-O-glucoside } \\
\text { Scutellarein } \\
\text { 6-hydroxyluteolin } \\
\text { Plantaginin } \\
\text { 6-hydroxyluteolin 7-O-glucoside }\end{array}$ & Aucubin \\
\hline P. depressa & $\begin{array}{l}\text { Acteoside } \\
\beta \text {-hydroxyacteoside } \\
\text { Campenoside } \\
\beta \text {-oxoacteoside } \\
\text { Orobanchoside } \\
\text { Cistanoside F }\end{array}$ & & Aucubin \\
\hline P. major & $\begin{array}{l}\text { Plantamajoside } \\
\text { Acteoside } \\
\text { Isoplantamajoside }\end{array}$ & $\begin{array}{l}\text { Plantaginin } \\
\text { Homoplantaginin } \\
\text { 6-hydroxyluteolin 7-O-glucoside }\end{array}$ & $\begin{array}{l}\text { Aucubin } \\
\text { Geniposidic acid } \\
\text { Gardoside } \\
\text { Melittoside } \\
\text { Catalpol }\end{array}$ \\
\hline P. lanceolata & $\begin{array}{l}\text { Plantamajoside } \\
\text { Acteoside } \\
\text { Lavandulifolioside } \\
\text { Isoacteoside } \\
\text { Cistanoside F }\end{array}$ & & $\begin{array}{l}\text { Aucubin } \\
\text { Catalpol }\end{array}$ \\
\hline
\end{tabular}

Compounds in bold indicate the major components.

Plantamajoside を主成分とする P. asiatica と P. majorにはフラボノイド成分が共存し, 主フラボノ イド成分は plantaginin（含有量約 $0.2 \%$ ）で，その 一方 acteoside を主成分とする種からはフラボノイ ド成分の共存は見出されていない. 53 このように基 原植物はフラボノイド成分からもそれらを含有する ものとしないものの 2 群に分けられた。これらは HPLCによる成分パターン分析からも確認できる (Fig. 9).

4 種の基原植物いずれも aucubin を共通成分とし て多量（含有量 1-4\%）に含有している．特にそ の中でもP. lanceolata は aucubin の他に, 利尿作 用が知られている catalpol を多量（約 2\%）含有す ることで他と異なった特徵をもつている.

確認試験車前草は日本薬局方に第 10 改正ま では確認試験が記載されていなかった，著者は車前 草の特有成分である plantamajorside を指標とした TLC 法による確認試験を提唱し, 32) 第 11 改正から
本法 [本品の粉末 $2.0 \mathrm{~g}$ にメタノール $10 \mathrm{ml}$ を加え, 水浴上で 3 分間加温し, 冷後, 万過し, 万液を試料 溶液とする.この液につき, 薄層クロマトグラフ法 により試験を行う。試料溶液 $10 \mu \mathrm{l}$ を薄層クロマト グラフ用シリカゲルを用いて調製した薄層板にスポ ットする. 次に $n$-ブタノール/水/水酢酸 $(7: 2: 1)$ を展開溶媒として約 $10 \mathrm{~cm}$ 展開した後, 薄層板を 風乾する。これに塩化第二鉄試液を噴霧するとき, $R f$ 值 0.5 付近に暗青色のスポットを認める. ] が記 載されることとなった. Plantamajoside と acteoside では $R f$ 值に明らかな差が認められ, 本法によ り中国薬典に記載の P. asiatica と P. depressa の基 原の鑑別は容易となった.

生理活性車前草の薬効と何らかの関連が考え られるいくつかの生理活性について検討を行つた.

抗菌作用： 主フェニルエタノイド配糖体につい て黄色ブドウ球菌 Staphylococcus aureus 寺島株を 用い, 希釈法による試験で, plantamajoside と ac- 


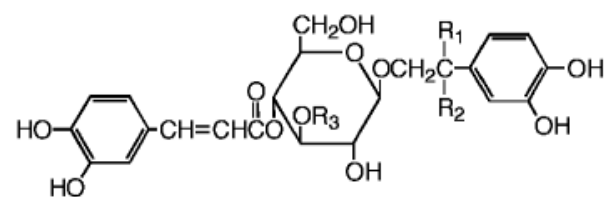

plantamajoside : $\mathrm{R}_{1}=\mathrm{R}_{2}=\mathrm{H}, \mathrm{R}_{3}=$ glucosyl hellicoside : $\mathrm{R}_{1}=\mathrm{H}, \mathrm{R}_{2}=\mathrm{OH}, \mathrm{R}_{3}=$ glucosyl acteoside : $\mathrm{R}_{1}=\mathrm{R}_{2}=\mathrm{H}, \mathrm{R}_{3}=$ rhamnosyl $\beta$-hydroxyacteoside : $\mathrm{R}_{1}=\mathrm{H}, \mathrm{R}_{2}=\mathrm{OH}, \mathrm{R}_{3}=$ rhamnosyl campenoside : $\mathrm{R}_{1}=\mathrm{H}, \mathrm{R}_{2}=\mathrm{OCH}_{3}, \mathrm{R}_{3}=$ rhamnosyl $\beta$-oxoacteoside : $\mathrm{R}_{1}=\mathrm{R}_{2}=\mathrm{O}, \mathrm{R}_{3}=$ rhamnosyl lavandulifolioside : $\mathrm{R}_{1}=\mathrm{R}_{2}=\mathrm{H}, \mathrm{R}_{3}=$ rhamnosyl $\stackrel{2 \rightarrow 1}{\text { arabinosyl }}$

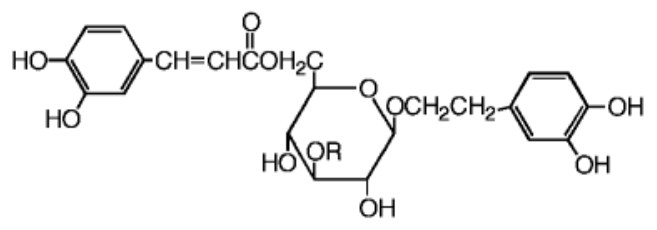

isoplantamajoside : $\mathrm{R}=$ glucosyl isoacteoside : $\mathrm{R}=$ rhamnosyl

3,4-dihydroxyphenethylalcohol-6- $O$-caffeoyl- $\beta$-D-glucoside: R=H

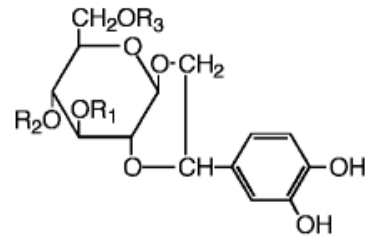

orobanchoside : $\mathrm{R}_{1}=$ rhamnosyl, $\mathrm{R}_{2}=$ caffeoyl, $\mathrm{R}_{3}=\mathrm{H}$ plantasioside : $R_{1}=R_{2}=H, R_{3}=$ caffeoyl<smiles>O=C1OC2(CO)OC(O)C(C=Cc3ccc(O)c(O)c3)C1O2</smiles>

cistanoside $\mathrm{F}: \mathrm{R}=$ rhamnosyl

Chart 3<smiles>[R6]Oc1cc(O)c2c(=O)cc(-c3ccc(O)c([R6])c3)oc2c1</smiles>

apigenin : $\mathrm{R}_{1}=\mathrm{R}_{2}=\mathrm{H}$

luteolin : $\mathrm{R}_{1}=\mathrm{H}, \mathrm{R}_{2}=\mathrm{OH}$

cosmosiin : $\mathrm{R}_{1}=$ glucosyl, $\mathrm{R}_{2}=\mathrm{H}$

luteolin 7-O-glucoside : $\mathrm{R}_{1}=$ glucosyl, $\mathrm{R}_{2}=\mathrm{OH}$<smiles>[R6]Oc1cc2oc(-c3ccc(O)c([R3])c3)cc(=O)c2c(O)c1O[R2]</smiles>

scutellarein : $\mathrm{R}_{1}=\mathrm{R}_{2}=\mathrm{R}_{3}=\mathrm{H}$ 6-hydroxyluteolin : $\mathrm{R}_{1}=\mathrm{R}_{2}=\mathrm{H}, \mathrm{R}_{3}=\mathrm{OH}$

plantaginin : $\mathrm{R}_{1}=$ glucosyl, $\mathrm{R}_{2}=\mathrm{R}_{3}=\mathrm{H}$

homoplantaginin : $\mathrm{R}_{1}=$ glucosyl, $\mathrm{R}_{2}=\mathrm{CH}_{3}, \mathrm{R}_{3}=\mathrm{H}$

6-hydroxyluteolin 7-O-glucoside : $\mathrm{R}_{1}=$ glucosyl, $\mathrm{R}_{2}=\mathrm{H}, \mathrm{R}_{3}=\mathrm{OH}$

Chart 4

teoside にそれぞれ最低阻止濃度（MIC）が $4.1 \mathrm{mM}$ $(2.7 \mathrm{mg} / \mathrm{ml})$ と $3.2 \mathrm{mM}(2.0 \mathrm{mg} / \mathrm{ml})$ の抗菌活性を 認めた. ${ }^{48)}$

酵素阻害作用： 牛の心臓からの cAMP-phosphodiesteraseを用いた phosphodiesterase 阻害活性 試験では P. asiatica とP. major の主成分に阻害活 性を認めた. ${ }^{48)}$

RBL-1 細胞からの 5-lipoxygenase を用いた試験で はやはり P. asiatica とP. major の主成分に阻害活 性を認めた（Table 3). ${ }^{48)}$

P. asiatica 中の plantamajoside は車前草を水で煎 じる過程で isoplantamajoside に転位することを見

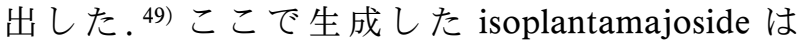
plantamajoside に比し, cAMP-phosphodiesterase 阻害活性において約 2 倍 $\left[\mathrm{IC}_{50}\left(\times 10^{-5} \mathrm{M}\right): 8.4\right], 5-$ lipoxygenase 阻害活性においては約 10 倍 $\left[\mathrm{IC}_{50}(\times\right.$ $\left.\left.10^{-7} \mathrm{M}\right): 0.41\right]$ の高い阻害活性を示した. このこと は車前草を煎液として利用する時の効果を考えた場 合に注目すべき点である。

肥満細胞からのヒスタミン遊離抑制作用： Compound 48/80 によるラット腹腔肥満細胞からの ヒスタミン遊離の抑制試験ではフェニルエタノイド 


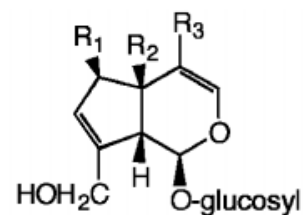

aucubin : $\mathrm{R}_{1}=\mathrm{OH}, \mathrm{R}_{2}=\mathrm{R}_{3}=\mathrm{H}$

geniposidic acid : $\mathrm{R}_{1}=\mathrm{R}_{2}=\mathrm{H}, \mathrm{R}_{3}=\mathrm{COOH}$

melittoside : $\mathrm{R}_{1}=\mathrm{OH}, \mathrm{R}_{2}=\mathrm{O}$-glucosyl, $\mathrm{R}_{3}=\mathrm{H}$

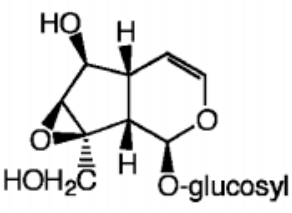

catalpol<smiles>C=C1[C@H]2C(OC(=O)O)=COC(=O)[C@@H]2C[C@H]1O</smiles>

gardoside

Chart 5
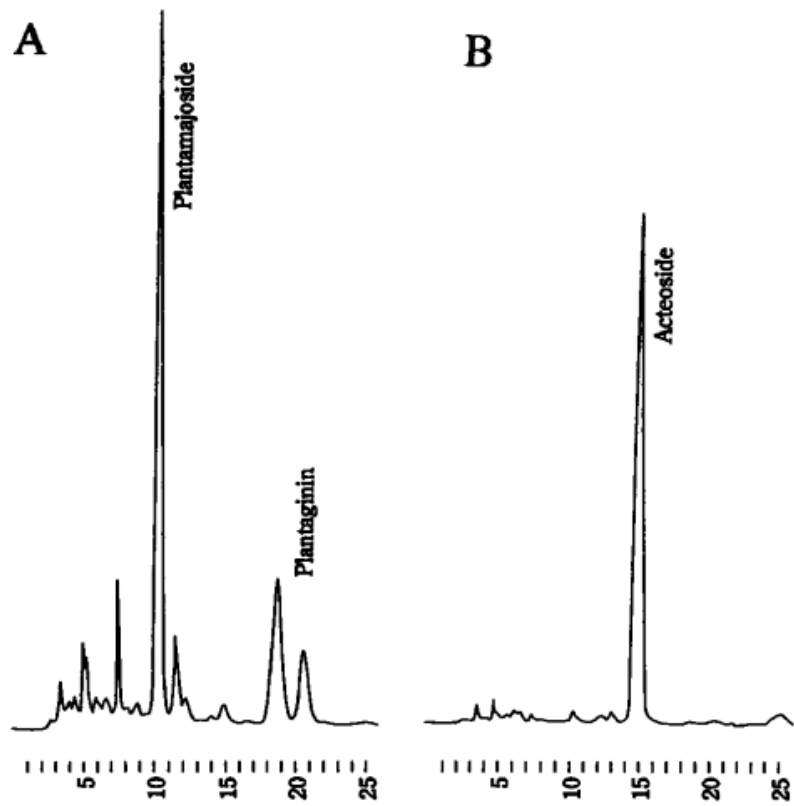

Fig. 9. HPLC Chromatograms of Methanol Extracts of Plantago Herb

A: $P$. asiatica, B: $P$. lanceolata, Conditions; column, Develosil ODS-5 $(4.6 \times 250 \mathrm{~mm})$; mobil phase, $\mathrm{MeOH}: \mathrm{H}_{2} \mathrm{O}: \mathrm{AcOH}(9: 29: 2)$; flow rate, $1.0 \mathrm{ml} / \mathrm{min}$; column temp., $35^{\circ} \mathrm{C}$; detector, UV $330 \mathrm{~nm}$.

配糖体やフラボノイド配糖体には活性を認めなかつ たが apigenin, luteolin, scutellarein, 6-hydroxyluteolin にそれぞれ $\left[\mathrm{IC}_{50}\left(\times 10^{-4} \mathrm{M}\right): 1.5,0.54,1.4,0.49\right]$ を認めた. ${ }^{57)}$ 国立衛研の川崎らは TNF-IgE と DNPBSA によるラット RBL-2H3 細胞からのヒスタミン 遊離の抑制試験で，フラボノイドに関し，同様の結 果を報告するとともに, scutellareinの細胞毒性が 最も低いことを見出している. ${ }^{58)}$

抗アレルギー作用： P. asiatica の主成分 plantamajoside とP. lanceolata $の$ 主成分 acteoside につ いてアラキドン酸により誘発されるマウスの耳急性 炎症モデルを用いた抗アレルギー試験を検討し た. ${ }^{55)} そ の$ 結果 plantamajoside に高い炎症抑制作用
Table 3. Enzyme Inhibitory Activity

\begin{tabular}{lccc}
\hline \hline & $\begin{array}{c}\text { cAMP } \\
\text { phosphodiesterase* }\end{array}$ & & 5-lipoxygenase** \\
\cline { 2 - 2 } Plantamajoside & 16.0 & & 3.73 \\
Hellicoside & 16.9 & 3.16 \\
Plantaginin & 1.4 & 1.20 \\
Acteoside & $>50$ & 13.6 \\
$\beta$-hydroxyacteoside & $>50$ & 49.8 \\
\hline
\end{tabular}

* From beef heart. ${ }^{* *}$ From RBL-1 cells.

Table 4. Inhibitory Effect on Arachidonic Acid-Induced Mouse Ear Edema

\begin{tabular}{lcccc}
\hline \hline & $\left.\begin{array}{c}\text { Dose } \\
\mathrm{mg} / \\
\text { ear }\end{array}\right)$ & $\begin{array}{c}\text { Increase of ear thickness } \\
\left(\times 10^{-2} \mathrm{~mm}\right)\end{array}$ & $\begin{array}{c}\text { Inhibition } \\
(\%)\end{array}$ \\
\cline { 3 - 4 } & 1 & $31.1 \pm 1.6$ & $29.2 \pm 1.2$ & $(n=6) 6$ \\
Acteoside & 3 & $29.4 \pm 1.5$ & $\left.25.2 \pm 0.5^{a}\right)$ & $(n=7) 14$ \\
Plantamajoside & 1 & $29.0 \pm 1.5$ & $24.4 \pm 1.5$ & $(n=6) 12$ \\
& 3 & $30.3 \pm 1.1$ & $22.6 \pm 0.7^{b)}$ & $(n=7) 25$ \\
\hline Phenidone* & 0.1 & $31.1 \pm 1.0$ & $19.2 \pm 0.5^{b)}$ & $(n=7) 38$ \\
\hline
\end{tabular}

Each value represents the mean \pm S.E. Significantly different from the control, a) $p<0.05, b) p<0.01$. * As reference compound.

が認められ，酵素阻害活性の結果とよく一致した (Table 4).

次に plantaginin がアナフラキシー反応に対して

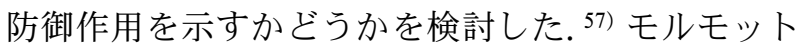
を卵白アルブミンで感作し， 3 週間後に卵白アルブ ミンのエアゾルを吸入させるとアナフィラキシーの 前駆症状として頸部及び腹部に疰攣がみられる。さ らに吸入を続けると強いショック症状を引き起こし 死亡する。この前駆症状の発現時間を測定し，つい で 1 週間 plantaginin を投与し, 投与終了翌日に再 
Table 5. Anti-Allergic Effect of Plantaginin on Preconvulsion Time Caused by Spraying Antigen-Aerosol to Sensitized Guinea Pig with Egg Albumin

\begin{tabular}{ccc}
\hline \hline $\begin{array}{c}\text { Days after beginning } \\
\text { of experiment }\end{array}$ & $\begin{array}{c}\text { Nomal } \\
(n=2)\end{array}$ & $\begin{array}{c}\text { Treated } \\
(50 \mathrm{mg} / \mathrm{kg} / \mathrm{day}, \mathrm{i} . \mathrm{p} .) \\
(n=2)\end{array}$ \\
\hline 0 & $114.19 \pm 9.19$ & $105.92 \pm 0.92($ second $)$ \\
7 & $143.54 \pm 4.10$ & $239.57 \pm 45.2$ \\
\hline Protection ratio & $1.26 \pm 0.065$ & $2.26 \pm 0.41$ \\
\hline & &
\end{tabular}

び卵白アルブミンの吸入を行い, 前駆症状の発現時 間を測定し，投与前の前駆症状の発現時間に対する 比を防御比として示した。 その結果，投与群では防 御比は対照群に比べて約 2 倍に増加し, 明らかなア ナフィラキシー反応に対する防御作用を示した (Table 5).

抗炎症作用： 車前草の水抽出エキスはラットの カラゲニン浮腫に対し，抗炎症作用を示した。

主成分の plantamajoside についても同様に抗炎 症作用の試験を行ったが活性は認められなかった。

M. C. Recio らは aucubin がカラゲニン浮腫に対し て抗炎症作用のあることを報告しており, ${ }^{59)}$ 車前草 エキスのカラゲニン浮腫に対する抗炎症作用は aucubin によることが考えられる.

抗酸化作用： 最近，抗酸化成分が老化予防をは じめとする種々の疾患予防と関連することが知られ てきた.

主成分の plantamajoside と acteoside について $\alpha, \alpha$-diphenyl- $\beta$-picrylhydrazy （DPPH） を用いるラ ジカル捕捉作用を検討した。 ${ }^{60)}$ その結果，いずれも 同程度の活性 $\left[\mathrm{IC}_{0.200}(\mu \mathrm{M})\right.$ : plantamajoside, 3.9, acteoside 3.9] を認め, $\alpha$-tocopherol $\left[\operatorname{IC}_{0.200}(\mu \mathrm{M}): 8.9\right]$ より高い活性を示した。一方ラット肝ミトコンドリ アにおけるADP- 鉄によって誘導される過酸化脂 質生成反応の抑制効果では acteoside $\left[\operatorname{IC}_{50}(\mu \mathrm{M})\right.$ : 26.7] の方が plantamajoside $\left[\mathrm{IC}_{50}(\mu \mathrm{M}): 44.3\right]$ よ り高い抑制効果を示した.

鎮痛作用：千葉大学の山崎, 奥山らの研究グ ループは acteoside に酢酸ライジング抑制活性を認 めている. その後 P. asiatica をはじめ, 各種植物 から単離されたフェニルエタノイド配糖体について 抑制活性の検討が行われたが acteosideより活性の 強いものは見出されなかった. ${ }^{61)}$
Table 6. IC $\mathrm{IC}_{50}$ of Flavonoids on HIV-Reverse Transcriptase

\begin{tabular}{|c|c|}
\hline Compound & $\mathrm{IC}_{50}(\mu \mathrm{M})$ \\
\hline Baicalein & 5.6 \\
\hline Apigenin & -a) \\
\hline Luteolin & 17.5 \\
\hline Scutellarein & 2.5 \\
\hline 6-hydroxyluteolin & 0.7 \\
\hline Baicalin & 30.1 \\
\hline Apigenin $7-O$-glucoside & -b) \\
\hline Luteolin 7-O-glucoside & 40.2 \\
\hline Plantaginin & 8.9 \\
\hline Homoplantaginin & 43.3 \\
\hline 6-hydroxyluteolin 7-O-glucoside & 4.3 \\
\hline
\end{tabular}

- : no appreciable inhibition at concentrations up to a) $20 \mu \mathrm{M}$ and b) $50 \mu \mathrm{M}$

Acteoside に関してはその他，抗腎炎効果が報告 され，その効果は抗原提示細胞の活性化とそれに続 く白血球の接着の抑制による糸球体内白血球浸潤の 抑制によるものと考えられている。

抗 HIV 作用： オウゴンからの baicalein に HIV 逆転写酵素阻害効果が報告されている. ${ }^{62)}$ Baicalein の構造と類似した P. asiatica からのフラボノイド にも HIV 逆転写酵素阻害効果が期待された。そこ で HIV 逆転写酵素阻害効果を HIV-1 の逆転写酵素 の鋳型 RNA $\left((\mathrm{rA})_{\mathrm{n}} \cdot(\mathrm{dt})_{12} \cdot 18\right)$ への $\left[{ }^{3} \mathrm{H}\right] \mathrm{dTTP}$ の取り込みに基づく放射活性により検討を行っ た。 ${ }^{63)}$ その結果，6-hydroxyluteolin に最も強い阻害 効果を認め, 次に scutellarein, baicalein, luteolin の 順で，配糖体にはかなりの効果の低下がみられた。 フラボノイドが高い阻害効果を示すためには芳香環 に互いに隣接した 2 個ないし 3 個の水酸基の存在と それと共役した芳香環の存在が必要ではないかと思 われる (Table 6).

まとめ 車前草の薬効には，傷薬としては抗菌 作用と鎮痛作用が，鎮咳（慢性気管支炎）には抗ア レルギー作用が，利尿と消炎には抗炎症作用が，老 化予防（強壮）には抗酸化作用がそれぞれ関与し, これらの作用は主成分の plantamajoside, acteoside, plantaginin, aucubin, catalpol どのもつ生理活性 に基づくものと思われる，従来いずれの基原による 車前草も同じ鎮咳，利尿，消炎などの薬効がうたわ れている。これまでの結果をふまえれば，車前草は 基原植物の違いにより，例えば, plantamajoside を 
主とするP. asiatica と acteoside, catalpol を主とす るP. lanceolata とは用途の使い分けが必要であろ う.

\section{おわりに}

絡石藤, 連趐, 車前草の研究にあたり, 北海道医 療大学薬学部生薬学教室員蒲原 (千葉) 真理子, 岡部和子, 菅原（北川）静香，村井（笹原）道子, 竹中孝子, 野口由香里, 佐久嶋明世博士, 大学院生 （故）塚本博樹博士，藤本啓博士，藤川隆彦博士， 玉山靖彦, 歯学部 馬場久衞教授, 遼寧中医学院 焦宝博士, Royal Danish School of Pharmacy Dr. Helle Ravn, Montpellier University Prof. Claude Andary, 岐阜薬科大学 田中俊弘教授, 酒井英二 博士, 名城大学薬学部 野呂征男教授, 川村智子博 士, 東邦大学薬学部 二階堂保教授, 名古屋市立大 学薬学部 荻原幸夫教授, 能勢充彦博士, 静岡県立 大学薬学部 野呂忠敬教授の各氏をはじめ, 多くの 国内並びに海外の大学及び研究所の方々にご協力を 頂きました．ここに厚くお礼申し上げます。

\section{REFERENCES}

1) Kosuge T., Yokota M., Sugiyama K., Yamamoto T., Mure T., Kuroki Y., Kose T., Yamazawa H., Yakugaku Zasshi, 105, 845847 (1985).

2) Chinese Pharmacopeia Committe of Ministry of Public Health of the People's Republic of China, “The Chinese Pharmacopeia（中華人 民共和国葯典),” Chemical and Technical Press, Beijing, 2000, pp. 221-222.

3) Beijing Municipal Institute for Drug Control and Chinese Academy of Plant Sciences (北京 薬品生物製品検定所, 中国科学院植物研究 所), “Zhongyao-jianbieshouce Vol. 1 (Handbook for Identification of Traditional Chinese Medicines Vol. 1)（中葯鑑別手冊 第一冊), ” Science Press, Beijing, 1981, pp. 379-384.

4) Nishibe S., Han Y., Noguchi Y., Sakai E., Tanaka T., Natural Medicines, 56, 40-46 (2002).

5) Nishibe S., Sakushima A., Noro T., Fukushima S., Shoyakugaku Zasshi, 41, 116-120 (1987).

6) Fujimoto T., Nose M., Takeda T., Ogihara Y., Nishibe S., Minami M., Shoyakugaku Zasshi, 46, 224-229 (1992).
7) Nishibe S., Hisada S., Inagaki I., Phytochemistry, 10, 3296-3297 (1971).

8) Fujimoto T., Nose M., Takeda T., Ogihara Y., Nishibe S., Shoyakugaku Zasshi, 47, 218221 (1993).

9) Nishibe S., Han Y., Noguchi Y., Ueda H., Yamazaki M., Mizutani K., Kambara T., Kishida N., Natural Medicines, 55, 205-208 (2001).

10) Nikaido T., Ohmoto T., Sankawa U., Tomimori T., Miyaichi Y., Imoto Y., Chem. Pharm. Bull., 36, 654-661 (1988).

11) Park K. Y., Lee S. H., Min B. K., Lee K. S., Choi J. S., Chung S. R., Min K. R., Kim Y. S., Planta Med., 65, 457-459 (1999).

12) Ichikawa K., Kinoshita T., Nishibe S., Sankawa U., Chem. Pharm. Bull., 34, 3514-3517 (1986) .

13) Matsumoto T., Kiyohara H., Nishiyama K., Yamada H., J. Trad. Med., 18, 108 (2001).

14) Takasaki M., Konoshima T., Komatsu K., Tokuda H., Nishino H., Cancer Lett., 158, 53 -59 (2000).

15) Takasaki M., Konoshima T., Nishibe S., Tsuha T., Tokuda H., Abstract of papers, The 48 th Annual Meeting of the Japanese Society of Pharmacognosy, Kanazawa, September 2001, p. 91 .

16) Hirose M., Yamaguchi T., Lin C., Kimoto N., Futakuchi M., Kono T., Nishibe S., Shirai T., Cancer Lett., 155, 79-88 (2000) .

17) Nose M., Fujimoto T., Takeda T., Nishibe S., Ogihara Y., Planta Med., 58, 520-523 (1992).

18) Nose M., Fujimoto T., Nishibe S., Ogihara Y., Planta Med., 59, 131-134 (1993).

19) Private letters from Dr. Niina Saarinen of University of Turku, Finland.

20) Tanaka T., Sakai E., Mitsui N., Yoshida M., Nishibe S., Shoyakugaku Zasshi, 43, 300-304 (1989).

21) Nishibe S., Chiba M., Hisada S., Yakugaku Zasshi, 97, 1134-1137 (1977).

22 ) Chiba M., Hisada S., Nishibe S., Shoyakugaku Zasshi, 32, 194-197 (1978) .

23) Chiba M., Tsukamoto H., Hisada S., Nishibe S., Shoyakugaku Zasshi, 33, 150-154 (1979).

24) Nishibe S., Chiba M., Hisada S., Shoyakugaku Zasshi, 31, 131-135 (1977).

25) Nishibe S., Okabe K., Tsukamoto H., 
Sakushima A., Hisada S., Chem. Pharm. Bull., 30, 1048-1050 (1982) .

26) Nishibe S., Okabe K., Tsukamoto H., Sakushima A., Hisada S., Baba H., Akisada T., Chem. Pharm. Bull., 30, 4548-4553 (1982)

27) Kitagawa S., Tsukamoto H., Hisada S., Nishibe S., Chem. Pharm. Bull., 32, 12091213 (1984).

28) Kitagawa S., Hisada S., Nishibe S., Phytochemistry, 23, 1635-1636 (1984).

29) Noro Y., Hisata Y., Okuda K., Kawamura T., Tanaka T., Nishibe S., Shoyakugaku Zasshi, 45, 327-332 (1991).

30) Nishibe S., Kawamura T., Tanaka T., Adlercreutz H., Natural Medicines, 55, 300-303 (2001).

31) Unpublished data.

32) Nishibe S., Sasahara M., Miyageta M., Noro Y., Kawamura T., Tanaka T., Yakugaku Zasshi, 110, 453-456 (1990).

33) Nishibe S., Noguchi Y., Yoshida A., Kawamura T., Natural Medicines, 55, 272275 (2001)

34) Kitagawa S., Nishibe S., Baba H., Yakugaku Zasshi, 107, 274-278 (1987).

35) Nikaido T., Ohmoto T., Kinoshita T., Sankawa U., Nishibe S., Hisada S., Chem. Pharm. Bull., 29, 3586-3592 (1981).

36) Nishibe S., Kitagawa S., Hisada S., Baba H., Yasui S., Narita T., Yoshioka K., J. Pharmacobio-Dyn., 10, s-48 (1987).

37) Kimura Y., Okuda H., Nishibe S., Arichi S., Planta Med., 2, 148-153 (1987).

38) Cho J. Y., Kim A. R., Park M. H., Planta Med., 67, 312-316 (2001).

39) Jiangsu New Medical College, ed., "Chinese Materia Medica Dictionary (中葯大辞典),” Shanghai Sci. and Tech. House, Shanghai, 1978, p. 1114.

40) Adlercreutz H., Fotsis T., Heikkinen R., Dwyer J. T., Woods M., Goldin B. R., Gorbach S. L., Lancet, 2, 1295-1299 (1982) .

41) Ohigashi H., Osawa T., Terao J., Watanabe S., Yoshikawa T., eds., "Food Factors for Cancer Prevention," Springer-Verlag, Tokyo, 1997, pp. 587-592.

42) Borriello S. P., Setchell K. D. R., Axelson M., Lawson A. M., J. Appl. Bacteriol., 58, 37-43
(1985)

43) Heinonen S., Nurmi T., Liukkonen K., Poutanen K., Rafaelli B., Wahala K., Deyama T., Nishibe S., Adlercreutz H., J. Agric. Food Chem., 49, 3133-3139 (2001).

44) Dinkova-Kostova A. T., Gang D. R., Davin L. B., Bedgar D. L., Chu A., Lewis N. G., J. Biol. Chem., 271, 29473-29482 (1996).

45) Hansel R., Keller K., Rimpler H., Schneider G., "Handbuch der Pharmazeutischen Praxis", Springer Verlag, Berlin, Heidelberg, New York, 1994, p. 221.

46) Morita N., Yoshizaki M., "Photographs of Medicinal Plants in Paraguay," JICA, 1991, p. 44.

47) Noro Y., Hisata Y., Okuda K., Kawamura T., Kasahara Y., Tanaka T, Sakai E., Nishibe S., Sasahara M., Shoyakugaku Zasshi, 45, 24-28 (1991)

48) Ravn H., Nishibe S., Sasahara M., Li X., Phytochemistry, 29, 3627-3631 (1990).

49) Sasahara M., Tamayama Y., Fujimoto T., Nishibe S., Tanaka T., Shoyakugaku Zasshi, 46, 268-272 (1992).

50) Nishibe S., Sasahara M., Jiao Y., Yuan C. L., Tanaka T., Phytochemistry, 32, 975-977 (1993).

51) Jiao Y., Sasahara M., Nishibe S., Yuan C. L., Tanaka T., Shoyakugaku Zasshi, 47, 330-333 (1993).

52) Andary C., Wylde R., Maury L., Heitz A., Dubourg A., Nishibe S., Phytochemistry, 37, 855-857 (1994).

53) Nishibe S., Murai M., Tamayama Y., Natural Medicines, 49, 340-342 (1995).

54) Nishibe S., Tamayama Y., Sasahara M., Andary C., Phytochemistry, 38, 741-743 (1995) .

55) Murai M., Tamayama Y., Nishibe S., Planta Med., 61, 479-480 (1995).

56) Murai M., Takenaka T., Nishibe S., Natural Medicines, 50, 306 (1996).

57) Tamayama Y., MS Thesis, Health Sciences University of Hokkaido, 1992.

58) Kawasaki M., Toyoda M., Teshima R., Sawada J., Hayashi T., Arisawa M., Shimizu M., Morita N., Inoue S., Saito Y., J. Food Hyg. Soc. Japan, 35, 497 (1994) .

59) Recio M. C., Giner R. M., Manez S., Rios J. I., Planta Med., 60, 232-234 (1994). 
60) Hori H., Ishibashi M., Mohamad S. B., Nagasawa H., Uto Y., Sakamaki H., Pan N., Ohkura K., Nishibe S., Adv. Exp. Med. Biol., 471, 395-401 (1999).

61) Nakamura T., Okuyama E., Tsukada A., Yamazaki M., Satake M., Nishibe S., Deyama T., Moriya A., Maruno M., Nishimura H.,
Chem. Pharm. Bull., 45, 499-504 (1997).

62) Ono K., Nakane H., Fukushima M., Chermann J. C., Barre-Sinoussi F., Biochem. Biophys. Res. Commun., 160, 982 (1989).

63) Nishibe S., Ono K., Nakane H., Kawamura T., Noro Y., Tanaka T., Natural Medicines, 51, 547-549 (1997). 